\title{
PENGARUH PENERAPAN METODE MIND MAPPING TERHADAP HASIL BELAJAR IPS KELAS VIII DI SMP N 6 PURWOKERTO
}

\author{
Ristiyani \\ Fakultas Ekonomi dan Bisnis, Jurusan Manajemen, Universitas Jenderal Soedirman \\ Email corresponding author: ristiyani917@gmail.com
}

\begin{abstract}
Abstrak
Penelitian ini merupakan penelitian Eksperimen Murni (True Experiment) dengan desain penelitian Control Group Posttest Only Design. Penelitian ini mengambil judul "Pengaruh Penerapan Metode Mind Mapping Terhadap Hasil Belajar Ilmu Pengetahuan Sosial (IPS) Kelas VIII di Sekolah Menengah Pertama Negeri 6 Purwokerto (SMP N 6 Purwokerto)". Tujuan penelitian ini adalah untuk mengetahui pengaruh penerapan metode mind mapping terhadap hasil belajar IPS. Populasi dalam penelitian ini adalah kelas VIII SMP N 6 Purwokerto. Sampel yang diambil dalam penelitian ini adalah kelas VIII D sebagai kelas eksperimen yang berjumlah 35 siswa dan kelas VIII E sebagai kelas kontrol yang berjumlah 34 siswa. Teknik sampel yang digunakan adalah Cluster Random Sampling.

Hasil penelitian menunjukkan bahwa terdapat pengaruh penerapan metode mind mapping terhadap hasil belajar IPS kelas VIII di SMP N 6 Purwokerto. Hasil belajar IPS lebih tinggi menggunakan metode mind mapping dari pada menggunakan metode ceramah. Hasil analisis data dengan menggunakan Microsoft Excel dan software SPSS 16 for windows menunjukkan rata-rata nilai yang diperoleh kelas eksperimen yaitu 80,2 sementara kelas kontrol sebesar 72,4. Metode pembelajaran mind mapping berpengaruh efektif terhadap hasil belajar siswa. Pengaruh metode pembelajaran mind mapping terhadap hasil belajar ditandai dengan nilai $t$ hitung $>t$ tabel yaitu 3,958 > 1,980 dan rata-rata nilai kelas eksperimen lebih tinggi dibandingkan dengan kelas kontrol yaitu $80,2>72,4$.
\end{abstract}

Kata kunci : Mind Mapping, Hasil Belajar.

\begin{abstract}
This is a True Experiment study by using Posttest Only Control Group Design with the title "The Influence of Mind Mapping Method Implementation on the learning outcomes of Social Science Class in State Junior High School 6 Purwokerto Grade VIII". This study aims to determine the effect of applying the mind mapping method to the learning outcomes of Social Science Class. Population used in this research is grade VIII in SMP N 6 Purwokerto. The sample taken in this research is class VIII D as experimental class with 35 students and class VIII E as control class with 34 students. Besides, the sampling technique used is Cluster Random Sampling.

This research shows that there is influence of the application of mind mapping method in the learning outcomes of Social Science Class in grade VII in State Junior High School 6 Purwokerto. The student's achiement using the mind mapping method is higher than using the lecturing method. The results of data analysis using Microsoft Excel and SPSS 16 for windows software shows the average value obtained by the experimental class is 80,2 while the control class is 72,4 . Mind mapping learning is proved effective to improve student learning achievement. The influence of mind mapping learning method to learning result is marked by $t$ count $>t$ table that is $3,958>1,980$ and mean of experiment class value is higher than control class that is $80,2>72,4$. The implication of this research is to improve the learning result of social science class, the teacher is expected to apply the mind mapping method in IPS learning to improve the learning outcomes and hopefully can provide enough tools and materials for making mind map.
\end{abstract}

Keywords : Mind Mapping, Learning Outcome. 


\section{PENDAHULUAN}

Negara Indonesia sebagai salah satu negara berkembang tidak akan mampu maju sepanjang belum meningkatkan kualitas sumber daya manusianya. Kualitas sumber daya manusia bisa meningkat salah satunya dengan pendidikan. Masalah kualitas pendidikan menjadi perhatian dunia pendidikan saat ini. Kualitas pendidikan dapat dilihat salah satunya dari kegiatan belajar mengajar. Keberhasilan proses belajar-mengajar dalam suatu lembaga pendidikan dapat dilihat dari hasil belajar yang dicapai oleh siswa.

Hasil belajar merupakan gambaran keberhasilan siswa dalam proses belajar yang ditandai dengan banyaknya nilai siswa yang mencapai Kriteria Ketuntasan Minimal (KKM) dan banyaknya lulusan yang masuk ke jenjang pendidikan yang lebih tinggi yang sesuai harapan siswa. Menurut Kustono (2016) dalam penelitiannya menyatakan kualitas pendidikan tidak terlepas dari hasil belajar dalam lingkup pendidikan formal. Standar pengukuran yang menunjukan kemampuan siswa memahami materi pelajaran dapat diketahui dari hasil belajar yang dinyatakan dalam bentuk angka. Hasil belajar tersebut dapat diketahui menggunakan Kriteria Ketuntasan Belajar Minimal (KKM).

Menurut Sutanto (2015:12) belajar merupakan suatu proses perkembangan artinya bahwa secara kodrati jiwa raga anak mengalami perkembangan sesuai dengan teori gestalf. Perkembangan sendiri memerlukan sesuatu baik yang berasal dari siswa sendiri maupun pengaruh dari lingkungan. Berdasarkan teori belajar ini hasil belajar siswa dipengaruhi oleh dua hal yaitu siswa itu sendiri dan lingkungan. Pertama, dapat dilihat dari siswa melalui kemampuan berfikir atau tingkah laku intelektual, motivasi, minat, dan kesiapan siswa, baik jasmani maupun rohani. Kedua, dari lingkungan yaitu sarana dan prasarana, kompetensi guru, kreativitas guru, sumber-sumber belajar, metode pembelajaran, keluarga dan lingkungan. Berdasarkan pernyataan tersebut dijelaskan bahwa metode pembelajaran adalah salah satu faktor yang mempengaruhi hasil belajar.

Metode pembelajaran adalah suatu cara yang dilakukan seorang guru untuk menyampaikan materi kepada siswanya. Pemakaian metode pembelajaran mempunyai tujuan agar hasil pembelajaran menjadi optimal. Sebelum melakukan pemilihan terhadap metode pembelajaran guru harus mengetahui bagaimana cara menggunakan metode tersebut. Selain itu metode pembelajaran yang digunakan harus sesuai dengan materi dan tujuan pembelajaran. Menurut Mulyatiningsih (2014:233) metode dalam pembelajaran dibedakan menjadi beberapa macam yaitu: investigasi (investigation), penemuan (inquiry), discovery learning, pembelajaran berbasis masalah (problem based instruction), metode pemecahan masalah (problem solving), problem posing, mind mapping, ceramah, resitasi, praktik dan latihan, panel dan debat serta jigsaw. 
Sugiarto (2004:75) menyatakan bahwa mind mapping adalah teknik meringkas bahan yang perlu dipelajari dan memproyeksikan masalah yang dihadapi ke dalam bentuk peta atau teknik grafik sehingga lebih mudah memahami materi. Kegiatan ini sebagai upaya yang dapat mengoptimalkan fungsi otak kiri dan kanan yang kemudian dalam aplikasinya sangat membantu untuk memahami masalah dengan cepat karena telah terpetakan. Menurut Arifah (2015) dalam penelitiannya menyatakan metode mind mapping ini mendorong peserta didik untuk berpikir sesuai dengan alur berpikirnya yang mana dari hal tersebut dapat merangsang kreativitas peserta didik dan membentuk karakter peserta didik.

Sudjana dan Wari Suwariyah (2010:55) menyatakan bahwa metode pembelajaran mind mapping dapat mengetahui seberapa jauh pengetahuan para siswa mengenai pokok bahasan yang diajarkan, dapat menolong siswa dalam belajar bagaimana caranya belajar bermakna itu, dapat menciptakan kegiatan diskusi antara guru dan siswa sewaktu mengungkapkan konsepkonsep yang telah dibuat, dan dapat dijadikan alat evaluasi. Alimuddin (2011) dalam penelitiannya menyatakan metode pembelajaran yang baik digunakan guru adalah metode pembelajaran mind mapping yang dapat menarik perhatian, memotivasi, mengaktifkan, mengembangkan kemampuan siswa, dan menguatkan daya ingat siswa. Metode pembelajaran mind mapping adalah salah satu metode pembelajaran inovatif yang diharapkan dapat melibatkan siswa secara aktif dalam pembelajaran yang mengarah pada peningkatan hasil belajar.

Berdasarkan hasil survey, SMP N 6 Purwokerto adalah salah satu sekolah menengah pertama yang masih menggunakan Kurikulum Tingkat Satuan Pendidikan (KTSP). Pembelajaran IPS yang dilaksanakan oleh guru menunjukan bahwa siswa kurang dapat menyerap dan menyimpan konsep-konsep yang sebelumnya sudah disampaikan oleh guru. Terbukti ketika guru memberi pertanyaan sebelum memasuki materi, kemampuan siswa untuk menjawab tidak merata, hanya satu sampai tiga anak saja yang mampu menjawab dengan benar.

Guru menggunakan metode ceramah dari awal hingga akhir pembelajaran. Kurangnya daya serap siswa pada mata pelajaran IPS salah satunya disebabkan oleh penggunaan metode pembelajaran yang kurang sesuai yaitu metode ceramah. Metode ceramah dapat menyebabkan kebosanan pada siswa apabila guru yang memberikan materi tersebut tidak dapat menyesuaikan dengan kondisi atau keadaan siswa serta dapat mematikan daya kreatifitas siswa dalam menggunakan semua aspek kecerdasannya karena dalam penggunaan metode ceramah siswa lebih banyak berdiam diri mendengarkan apa yang disampaikan guru tanpa ikut berpartisipasi secara aktif dalam pembelajaran.

Ketika proses pembelajaran guru hanya menampilkan buku teks yang juga dimiliki siswa. Guru mengajarkan konsep yang sama persis dengan apa yang terdapat dalam buku teks. Seolah-olah hanya buku teks tersebut yang menjadi acuan dalam pembelajaran IPS di 
kelas. Dalam proses pembelajaran guru menugaskan siswa untuk menulis rangkuman yang juga terdapat dalam buku teks. Siswa langsung memindah catatan dari buku teks ke buku mereka masing-masing. Siswa sebenarnya membuat rangkuman yang tidak efektif, karena tidak terlebih dahulu melalui proses pemahaman terhadap konsep. Hal ini yang menjadi akar masalah siswa sering lupa dengan konsep yang sebelumnya telah dipelajari bersama guru. Siswa menjadi malas membaca konsep yang telah mereka tulis dari rangkuman yang terdapat dalam buku teks karena tidak menarik, terlalu banyak kalimat dan tidak tepat sasaran. Kegiatan evaluasi pembelajaran juga diambil dari buku teks, yang kemudian dikerjakan siswa di buku mereka masing-masing.

Permasalahan ini mengakibatkan siswa tidak mencapai ketuntasan minimal dalam belajar. Terbukti dari hasil ulangan akhir semester untuk mata pelajaran Ilmu Pengetahuan Sosial (IPS) banyak siswa yang belum mencapai KKM. Hasil belajar tersebut dapat dilihat dari tabel 1.

Dilihat dari tabel 1. dapat diketahui bahwa sebagian siswa kelas VIII memperoleh nilai di bawah kriteria ketuntasan minimal. Siswa yang memperoleh nilai di bawah KKM sebanyak 161 siswa dari 257 siswa atau sebanyak 62,65\% siswa yang belum tuntas. Hal ini menunjukan bahwa nilai hasil belajar IPS untuk kelas VIII masih rendah.

Tabel 1. Hasil belajar IPS kelas VIII dilihat dari ulangan akhir semester gasal tahun ajaran $2017 / 2018$

\begin{tabular}{cccccc}
\hline No & Kelas & KKM & Tuntas & Belum Tuntas & Nilai Rata-Rata Kelas \\
\hline 1. & VIII A & 78 & 2 siswa & 34 siswa & 66,94 \\
2. & VIII B & 78 & 3 siswa & 33 siswa & 67,55 \\
3. & VIII C & 78 & 1 siswa & 35 siswa & 66,56 \\
4. & VIII D & 78 & 23 siswa & 14 siswa & 78 \\
5. & VIII E & 78 & 19 siswa & 17 siswa & 78,08 \\
6. & VIII F & 78 & 26 siswa & 12 siswa & 79,5 \\
7. & VIII G & 78 & 22 siswa & 16 siswa & 77,86 \\
\hline
\end{tabular}

Sumber : Guru mata pelajaran IPS kelas VIII SMP N 6 Purwokerto

Berdasarkan permasalahan tersebut solusi untuk mengatasi rendahnnya nilai hasil belajar IPS dapat diatasi dengan menggunakan metode pembelajaran yang mampu memberikan pemahaman konsep, mempermudah dalam mengingat materi dan mampu membangkitkan kreativitas siswa agar siswa dapat berperan aktif dalam pembelajaran yaitu menggunakan metode pembelajaran mind mapping. Penerapan metode pembelajaran mind mapping dalam kegiatan pembelajaran diharapkan dapat menimbulkan interaksi yang tinggi antara guru dan siswa ataupun antara siswa itu sendiri. Hal ini akan mengakibatkan suasana kelas menjadi aktif, kondusif serta tidak membosankan, dimana masing-masing siswa dapat menunjukkan kemampuan dalam merangkum materi seoptimal mungkin sesuai dengan alur berpikirnya. Dengan kesesuaian alur berpikir masing-masing siswa, nanti akan membentuk kreativitas dan 
membentuk pemahaman konsep yang akan mengarah pada penguatan daya ingat siswa dan merujuk pada peningkatan hasil belajar di sekolah.

Berdasarkan penelitian Faridah dan Woro Setyarsih (2014) menemukan bahwa hasil belajar siswa lebih baik menggunakan metode pembelajaran mind mapping dari pada metode pembelajaran ceramah sedangkan menurut penelitian Priantini, Dewa Ayu Made Manu Okta (2016) menemukan bahwa hasil belajar IPS siswa lebih baik menggunakan metode mind mapping dari pada metode pembelajaran konvensional.

Berdasarkan latar belakang di atas peneliti tertarik untuk meneliti hasil belajar IPS kelas VIII yang dipengaruhi oleh penggunaan metode pembelajaran mind mapping dengan tujuan untuk mengetahui pengaruh penerapan metode mind mapping terhadap hasil belajar IPS kelas VIII di SMP N 6 Purwokerto. Agar penelitian lebih fokus dan tidak meluas dari pembahasan yang dimaksud, maka dalam penelitian ini meneliti pada ruang lingkup penelitian yaitu pengaruh penerapan metode mind mapping terhadap hasil belajar IPS ranah kognitif kelas VIII di SMP N 6 Purwokerto.

\section{TINJAUAN PUSTAKA DAN PERUMUSAN HIPOTESIS}

\section{Hasil Belajar}

Menurut Trianto (2012:16) belajar adalah perubahan pada individu yang terjadi melalui pengalaman, dan bukan karena pertumbuhan dan perkembangan tubuhnya atau karakteristik seseorang sejak lahir. Menurut Slameto (2003:2) belajar adalah suatu proses usaha yang dilakukan seseorang untuk memperoleh suatu perubahan tingkah laku yang baru secara keseluruhan, sebagai hasil pengalamannya sendiri dalam interaksi dengan lingkungannya.

Sudjana (2014:22) mengatakan bahwa hasil belajar adalah kemampuan-kemampuan yang dimiliki siswa setelah ia menerima pengalaman belajarnya. Menurut Suprijono (2009:5) hasil belajar adalah pola-pola perbuatan, nilai-nilai, pengertian-pengertian, sikapsikap, apresiasi dan keterampilan.

Berdasarkan pendapat tersebut dapat disimpulkan bahwa hasil belajar adalah suatu tingkat keberhasilan seseorang dalam mempelajari sesuatu yang menyangkut aspek kognitif, afektif dan psikomotorik. Tabel 2. menunjukan indikator hasil belajar yang dapat digunakan sebagai acuan pengungkapan hasil belajar. Menurut Syah (2008:150) hasil belajar memiliki beberapa indikator yang pada prinsipnya pengungkapan hasil belajar ideal meliputi segenap ranah psikologis yang merubah sebagai akibat pengalaman dan proses belajar siswa.

Tabel 2. Indikator hasil belajar

\begin{tabular}{|c|c|c|}
\hline Ranah /Jenis Prestasi & Indikator & Cara evaluasi \\
\hline A. Ranah Cipta (Kognitif) & & \\
\hline 1. Pengamatan & $\begin{array}{ll}\text { - } & \text { Dapat menunjukan } \\
\text { - } & \text { Dapat membandingkan } \\
\text { - } & \text { Dapat menghubungkan }\end{array}$ & $\begin{array}{l}\text { - Tes lisan } \\
\text { - Tes tertulis } \\
\text { - Observasi/tes tertulis }\end{array}$ \\
\hline
\end{tabular}




\begin{tabular}{|c|c|c|}
\hline 2. Ingatan & $\begin{array}{ll}\text { - } & \text { Dapat menyebutkan } \\
\text { - } & \text { Dapat menunjukan } \\
& \text { kembali }\end{array}$ & $\begin{array}{l}\text { - Tes lisan/tes tertulis } \\
\text { - Tes tertulis }\end{array}$ \\
\hline 3. Pemahaman & $\begin{array}{l}\text { - Dapat menjelaskan } \\
\text { - Dapat mendefinisikan dengan } \\
\text { lisan sendiri }\end{array}$ & $\begin{array}{l}\text { - Tes lisan } \\
\text { - Tes tertulis }\end{array}$ \\
\hline 4. Penerapan & $\begin{array}{l}\text { - Dapat memberi contoh } \\
\text { - Dapat menggunakan secara } \\
\text { tepat }\end{array}$ & $\begin{array}{l}\text { - Tes tertulis } \\
\text { - Pemberian tugas } \\
\text { - Observasi }\end{array}$ \\
\hline 5. Analisis & $\begin{array}{ll}- & \text { Dapat menguraikan } \\
\text { - } & \text { Dapat mengklasifikasikan } \\
\end{array}$ & $\begin{array}{l}\text { - Tes tertulis } \\
\text { Pemberian tugas }\end{array}$ \\
\hline 6. Sintesis & $\begin{array}{ll}\text { - } & \text { Dapat menghubungkan } \\
\text { - } & \text { Dapat menyimpulkan } \\
\text { - } & \text { Dapat menggeneralisasikan }\end{array}$ & $\begin{array}{l}\text { - } \text { Tes tertulis } \\
\text { - Pemberian tugas }\end{array}$ \\
\hline \multicolumn{3}{|l|}{ B. Ranah Rasa (Afektif) } \\
\hline 1. Penerimaan & $\begin{array}{lll}\text { - } & \text { Menunjukan } & \text { sikap } \\
\text { menerima } & \\
\text { - } & \begin{array}{l}\text { Menunjukan } \\
\text { menolak }\end{array} & \text { sikap } \\
\end{array}$ & $\begin{array}{l}\text { - Tes tertulis } \\
\text { - Tes skala sikap } \\
\text { - Observasi }\end{array}$ \\
\hline 2. Sambutan & $\begin{array}{ll}\text { - } & \text { Kesediaan berpartisipasi } \\
\text { - } & \text { Kesediaan memanfaatkan }\end{array}$ & $\begin{array}{l}\text { - Tes tertulis } \\
\text { - Tes skala sikap } \\
\text { - Observasi }\end{array}$ \\
\hline 3. Apresiasi & $\begin{array}{llll}\text { - } & \begin{array}{l}\text { Menganggap } \\
\text { bermanfaat }\end{array} & \text { penting } & \text { dan } \\
\text { - } & \text { Menganggap indah } & \text { dan } \\
& \text { harmonis } & & \\
\text { - } & \text { Mengagumi } & & \\
\end{array}$ & $\begin{array}{l}\text { - Tes tertulis } \\
\text { - Tes skala sikap } \\
\text { - Observasi }\end{array}$ \\
\hline 4. Internalisasi & $\begin{array}{ll}- & \text { Mengakui dan meyakini } \\
\text { - } & \text { Mengingkari }\end{array}$ & $\begin{array}{l}\text { - Tes tertulis } \\
\text { - Tes skala sikap } \\
\text { - Observasi }\end{array}$ \\
\hline 5. Karakterisasi & $\begin{array}{ll}\text { - } & \text { Melembagakan } \\
\text { atau meniadakan } \\
\text { - } \\
\text { Menjelmakan dalam pribadi } \\
\text { dan perilaku sehari-hari }\end{array}$ & $\begin{array}{l}\text { - Tes skala sikap } \\
\text { - Observasi }\end{array}$ \\
\hline \multicolumn{3}{|l|}{$\begin{array}{ll}\text { C. } & \text { Ranah } \\
& \text { Karsa(Psikomotor) } \\
\end{array}$} \\
\hline $\begin{array}{l}\text { 1. Keterampilan } \\
\text { bergerak dan } \\
\text { bertindak }\end{array}$ & $\begin{array}{l}\text { - } \begin{array}{l}\text { Mengkoordinasikan gerak } \\
\text { mata, tangan, kaki dan } \\
\text { anggota tubuh lain }\end{array} \\
\end{array}$ & $\begin{array}{ll}\text { - } & \text { Observasi } \\
\text { - } & \text { Tes tindakan }\end{array}$ \\
\hline $\begin{array}{l}\text { 2. Kecakapan ekspresi } \\
\text { verbal dan nonverbal }\end{array}$ & $\begin{array}{ll}- & \text { Mengucapkan } \\
- & \text { Membuat mimik dan gerakan } \\
& \text { jasmani }\end{array}$ & $\begin{array}{ll}- & \text { Tes lisan } \\
\text { - } & \text { Observasi } \\
- & \text { Tes tindakan }\end{array}$ \\
\hline
\end{tabular}

Sumber : Syah (2008:151)

\section{Faktor-Faktor yang Mempengaruhi Hasil Belajar}

Menurut Ruseffendi dalam Sutanto (2015:14) mengidentifikasi faktor-faktor yang mempengaruhi hasil belajar kedalam sepuluh macam yaitu : 


\section{Kecerdasan Anak}

Kemampuan intelegensi seseorang sangat mempengaruhi terhadap cepat dan lambatnya penerimaan informasi serta terpecahnya atau tidaknya suatu permasalahan. Kecerdasan siswa sangat membantu pengajar untuk menentukan apakah siswa itu mampu mengikuti pelajaran yang diberikan dan untuk meramalkan keberhasilan siswa setelah mengikuti pelajaran yang diberikan meskipun tidak terlepas dari faktor lainnya.

\section{Kesiapan dan Kematangan}

Kesiapan dan kematangan adalah tingkat perkembangan dimana individu atau organorgan sudah berfungsi sebagaimana mestinya. Dalam proses belajar, kematangan atau persiapan ini sangat menentukan keberhasilan dalam belajar tersebut. Oleh karena itu, setiap upaya belajar akan lebih berhasil jika dilakukan bersamaan dengan tingkat kematangan individu, karena kematangan ini erat hubungannya dengan masalah minat dan kebutuhan anak.

\section{Bakat Anak}

Bakat adalah kemampuan potensial yang dimiliki seseorang untuk mencapai keberhasilan pada masa yang akan datang. Dengan demikian setiap orang sebenarnya memiliki bakat dalam arti berpotensi untuk mencapai prestasi sampai tingkat tertentu. Sehubungan dengan hal ini maka bakat akan dapat mempengaruhi tinggi rendahnya prestasi belajar.

\section{Kemauan Belajar}

Salah satu tugas guru yang kerap sukar dilaksanakan ialah membuat anak menjadi mau belajar atau menjadi giat untuk belajar. Keengganan siswa untuk beljar mungkin disebabkan karena ia belum mengerti bahwa belajar sangat penting untuk kehidupan kelak. Kemauan belajar yang tinggi disertai dengan rasa tanggung jawab yang besar tentunya berpengaruh positif terhadap hasil belajar yang diraihnya. Karena kemauan belajar menjadi salah satu penentu dalam mencapai keberhasilan belajar.

\section{Minat}

Minat adalaha kecenderungan dan kegairahan yang tinggi atau keinginan yang besar terhadap sesuatu. Seseorang siswa yang menaruh minat besar terhadap pelajaran akan memusatkan perhatiaanya lebih banyak dari pada siswa lainnya. Kemudian karena pemusatan perhatian yang intensif terhadap materi itulah yang memungkinkan siswa untuk belajar lebih giat dan akhirnya mencapai hasil belajar yang diinginkan.

\section{Model Penyajian Materi Pelajaran}

Keberhasilan siswa dalam belajar tergantung pula pada model penyajian materi. Model penyajian materi yang menyenangkan, tidak membosankan, menarik dan mudah 
dimengerti oleh siswa tentunya berpengaruh secara positif terhadap keberhasilan belajar.

\section{Pribadi dan Sikap Guru}

Siswa, begitu juga manusia pada umumnya dalam melakukan belajar tidak hanya melalui bacaan atau melalui guru saja, tetapi bias juga melalui contoh-contoh yang baik dari sikap , tingkah laku, dan perbuatan. Kepribadian dan sikap guru yang kreatifdan penuh inovatif dalam perilakunya maka siswa akan meniru gurunya yang aktif dan kreatif ini. Pribadi dan sikap guru yang baik tercermin dari sikapnya yang ramah, lemah lembut, penuh kasih sayang, membimbing dengan penuh perhatian, tidak cepat marah, tanggap terhadap keluhan atau kesulitan siswa,antusias dan semangat dalam bekerja dan mengajar, memberi penilaian yang objektif, rajin, disiplin, dan bertanggung jawab dalam segala tindakan.

\section{Suasana Pengajaran}

Suasana pengajaran yang tenang, terjadinya dialog yang kritis antara siswa dengan guru, dan menumbuhkan suasana yang aktif diantara siswa tentunya akan memberikan nilai lebih pada proses pengajaran sehingga keberhasilan siswa dalam belajar dapat meningkat secara optimal.

\section{Kompetensi Guru}

Guru yang professional memiliki kemampuan-kemampuan tertentu. Kemampuan itu diperlukan dalam membantu siswa dalam belajar. Keberhasilan siswa belajar akan banyak dipengaruhi oleh kemampuan guru yang professional.

\section{Masyarakat}

Bermacam-macam tingkah laku terdapat pada masyarakat dengan berbagai macam latar belakang pendidikan. Oleh karena itu pantaslah dalam dunia pendidikan lingkungan masyarakat ikut mempengaruhi kepribadian siswa.

Menurut Suryabrata (2014:233) hasil belajar dipengaruhi oleh beberapa faktor yaitu : (1) Faktor yang berasal dari luar diri pelajar dan ini dapat digolongkan menjadi dua golongan yaitu : (a) Faktor-faktor nonsosial; Kelompok faktor-faktor ini boleh dikatakan juga tidak terbilang jumlahnya seperti: keadaan udara, suhu udara, cuaca, waktu, tempat, alat-alat yang dipakai untuk belajar. (b) Faktor-faktor sosial; Faktor sosial yag dimaksud adalah faktor manusia, baik manusia itu ada maupun kehadirannya itu tidak dapat disimpulkan, jadi tidak langsung hadir. Kehadiran orang pada waktu seseorang sedang belajar dapat menggangu belajar misalnya satu kelas siswa sedang mngerjakan ujian lalu terdengar banyak anak bercakap-cakap di samping kelas. Faktor sosial seperti ini umumnya bersifat mengganggu proses belajar dan menggangu konsentrasi sehingga perhatian tidak dapat ditujukan kepada hal yang dipelajari atau aktivitas 
belajar itu semata-mata. Dengan berbagai cara faktor tersebut harus diatur supaya belajar dapat berlangsung sebaik-baiknya. (2) Faktor yang berasal dari dalam diri pelajar, dan ini dapat digolongkan menjadi dua golongan yaitu : (a) Faktor Fisiologis; Faktor fisiologis terdiri dari keadaan fungsi-fungsi jasmani terutama pancaindera dan tonis jasmani yang pada umumnya dapat dikatakan melatarbelakangi aktivitas belajar, keadaan jasmani yang segar akan lain pengaruhnya dengan keadaan jasmani yang kurang segar, keadaan yang lelah lain pengaruhnya dari pada yang tidak lelah. (b) Faktor Psikologis; Salah satu hal yang mendorong aktivitas belajar itu merupakan alasan dilakukannya perbuatan belajar itu.

\section{Metode Pembelajaran}

Menurut Djamarah (2002:53), metode adalah cara yang digunakan untuk mencapai tujuan yang ditetapkan. Metode dapat dianggap suatu prosedur atau proses yang teratur, suatu jalan atau cara yang teratur untuk melakukan segala sesuatu. Menurut Mulyatiningsih (2014:229) metode pembelajaran adalah cara yang digunakan untuk mengimplementasikan rencana yang disusun dalam bentuk kegiatan nyata atau praktis untuk mencapai tujuan pembelajaran. Menurut Sutanto (2015:133) metode pembelajaran adalah suatu cara atau alat yang dipakai oleh seorang pendidik dalam menyampaikan bahan pelajaran sehingga bisa diterima oleh siswa dan juga tercapainya tujuan yang diinginkan.

\section{Jenis-Jenis Metode Pembelajaran}

Menurut Mulyatiningsih (2014:233) mengemukakan jenis-jenis metode pembelajaran adalah sebagai berikut : (1) Metode Investigasi (investigation) (2) Metode Penemuan (inquiry) (3) Discovery Learning (4) Pembelajaran Berbasis Masalah (5) Metode Pemecahan Masalah (6) Problem Posing (7) Mind Mapping (8) Ceramah (9) Resitasi (10) Praktik dan Latihan (11) Panel dan Debat (12) Jigsaw.

Menurut Alimuddin (2011) dalam penelitiannya menyatakan bahwa salah satu karakteristik pelajaran IPS yaitu cenderung pada hafalan, oleh karena itu guru perlu menggunakan metode pembelajaran yang dapat membantu siswa mengingat. Mudahnya siswa mengingat apa yang dihafalkan dapat berdampak positif pada peningkatan hasil belajar IPS siswa. Metode pembelajaran mind mapping (peta pikiran) merupakan salah satu metode yang dapat membantu siswa dalam mengingat dan memudahkan siswa dalam memahami materi pembelajaran.

Menurut Handoko (2015) dalam penelitiannya yang berjudul "Pengaruh Penggunaan Mind Map Terhadap Hasil Belajar IPS Kelas V Semester Genap SD Negeri Margoyasan Yogyakarta Tahun Ajaran 2014/2015" menemukan perbedaan hasil belajar IPS antara siswa kelas V semester genap SD Negeri Margoyasan Yogyakarta tahun ajaran 2014/2015 yang mengikuti 
pembelajaran dengan menggunakan metode tipe mind mapping dengan siswa yang tidak mengikuti pembelajaran mind mapping. Penelitian ini menggunakan metode penelitian Quasi Eksperimental Design dengan menggunakan desain penelitian Nonequivalent control group design. Subjek penelitian adalah kelas VA sejumlah 20 peserta didik dan kelas VB sejumlah 21 peserta didik. Teknik analisis data menggunakan beda mean dan analisis deskriptif. Hasil penelitian menunjukkan nilai rata-rata hasil belajar IPS dan gain score kelas eksperimen lebih tinggi dibandingkan kelas kontrol setelah diberikan perlakuan.

Rumusan hipotesis yang diajukan yaitu:

$\mathrm{H}_{0}$ : Tidak terdapat pengaruh penerapan metode mind mapping terhadap hasil belajar IPS kelas VIII di SMP N 6 Purwokerto.

$\mathrm{H}_{1}$ : Terdapat pengaruh penerapan metode mind mapping terhadap hasil belajar IPS kelas VIII di SMP N 6 Purwokerto

\section{METODE PENELITIAN DAN TEKNIK ANALISIS DATA}

\section{Metode Penelitian}

Penelitian ini merupakan penelitian eksperimen murni (true experiment). Menurut Arifin (2012: 74) eksperimen murni bertujuan untuk menguji variabel bebas dan variabel terikat yang dilakukan terhadap sampel kelompok eksperimen atau kelompok kontrol. Sampel dari kedua kelompok diambil secara acak. Sampel acak bisa diambil jika subjek-subjek tersebut memiliki ciri yang sama. Desain penelitian eksperimen murni yang digunakan adalah Control group Posttest Only Design. Desain ini menggunakan dua kelompok subjek yang dibentuk secara acak dan diasumsikan memiliki karakteristik yang sama (homogen).

Satu kelompok diberi perlakuan (eksperimen), sementara yang satunya lagi dijadikan sebagai kelompok kontrol. Pada kedua kelompok tersebut diberikan post test (tesnya sama) kemudian diberikan perlakuan khusus untuk kelompok eksperimen. Hasil kedua post test dibandingkan atau diuji perbedaanya. Jika antara kedua post test pada kelompok eksperimen dan kelas kontrol menunjukan perbedaan, maka terdapat pengaruh dari perlakuan yang diberikan. Menurut Arifin (2012:81) desain penelitiannya dapat dilihat dari tabel 3.

Tabel 3. Desain penelitian

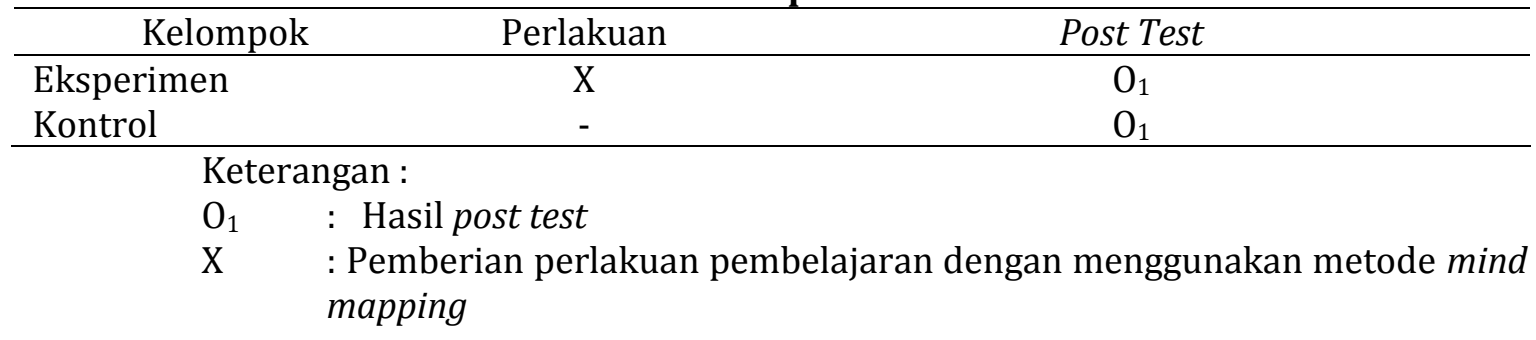




\section{Populasi dan Sampel}

Populasi adalah wilayah generalisasi yang terdiri atas objek/subjek yang mempunyai kualitas dan karakteristik tertentu yang ditetapkan oleh peneliti untuk dipelajari dan kemudian ditarik kesimpulannya (Sugiyono, 2012:61). Populasi dalam penelitian ini adalah siswa kelas VIII SMP N 6 Purwokerto yang berjumlah 257 siswa yang terdiri dari kelas VIIIA - VIIIG. Sampel adalah bagian dari jumlah dan karakteristik yang dimiliki oleh populasi. Bila populasi besar, dan peneliti tidak mungkin mempelajari semua yang ada pada populasi maka peneliti dapat menggunakan sampel yang diambil dari populasi itu (Sugiyono, 2012:62). Sampel penelitian ini diambil dengan teknik cluster random sampling terhadap kelas.

\section{Teknik Pengumpulan Data}

\section{Dokumentasi}

Teknik dokumentasi dilakukan untuk mengetahui daftar nama siswa yang menjadi responden dalam penelitian, hasil belajar IPS dan uji coba instrumen.

\section{Teknik Tes}

Teknik tes digunakan untuk mengetahui data tentang hasil belajar IPS siswa kelas VIII SMP N 6 Purwokerto. Tes tersebut dilaksanakan dengan ketentuan sebagai berikut:

$\begin{array}{ll}\text { Prosedur tes } & : \text { Post test } \\ \text { Jenis tes } & : \text { Tertulis } \\ \text { Bentuk tes } & : \text { Pilihan ganda }\end{array}$

\section{Teknik Analisis Data}

\section{Uji Rata-Rata}

Uji rata- rata digunakan untuk mengetahui kemampuan awal siswa yang dilakukan dengan cara membandingkan rata- rata nilai hasil belajar IPS sebelumnya di setiap kelas. Jika terdapat perbedaan rata- rata nilai yang jauh, maka penelitian tidak dapat dilaksanakan. Jika rata- rata nilai kedua kelas sama atau berbeda sedikit, penelitian dapat dilaksanakan karena perbedaan rata-rata nilai tidak terpaut jauh. Selain itu uji rata-rata digunakan juga pada akhir pembelajaran yang dilakukan dengan cara membandingkan rata-rata nilai hasil pos test kedua kelas untuk mengetahui perbedaan hasil belajar kedua kelas tersebut.

\section{Uji Normalitas}

Uji normalitas digunakan untuk mengetahui apakah data skor tes kelompok kontrol dan kelompok eksperimen berdistribusi normal atau tidak. Uji normalitas yang digunakan peneliti dalam penelitian ini adalah menggunakan uji Chi-Square. Menurut Sugiyono (2012:107) pengujian normalitas data dengan Chi-Square adalah teknik statistik yang digunakan untuk menguji hipotesis dalam populasi terdiri atas dua atau lebih kelas dimana data berbentuk 
nominal dan sampelnya besar. Menurut Sugiyono (2012:107) rumus dasar Chi-Square adalah sebagai berikut :

$\chi^{2}=\sum_{i=1}^{k} \frac{\left(f_{o}-f_{h}\right)^{2}}{f_{h}}$

Keterangan :

$\chi^{2}=$ Chi square

$\mathrm{f}_{0}=$ Frekuensi yang diobservasi

$\mathrm{f}_{\mathrm{h}}=$ Frekuensi yang diharapkan

Untuk membuat keputusan tentang hipotesis yang diajukan diterima atau ditolak, maka chi square tabel dengan dk dan taraf kesalahan tertentu. Dalam hal ini berlaku ketentuan bila chi kuadrat hitung lebih kecil dari tabel, maka $\mathrm{H}_{0}$ diterima, dan apabila lebih besar atau sama dengan harga table maka $\mathrm{H}_{\mathrm{O}}$ ditolak.

\section{Uji Homogenitas}

Jenis penelitian ini adalah penelitian eksperimen. Alat analisis yang digunakan dalam penelitian ini yaitu analisis uji homogenitas. Uji ini digunakan untuk mengetahui apakah kelompok kontrol dan kelompok eksperimen berawal dari populasi yang memiliki varian yang sama atau tidak. Menurut Mulyatiningsih (2014:92) menyatakan pengujian homogenitas varians suatu kelompok data, dapat dilakukan dengan cara Uji F. Rumus homogentitas menurut Mulyatiningsih (2014:92) adalah sebagai berikut:

$$
\mathrm{F}=\frac{\text { Varians terbesar }}{\text { Varians terkecil }}
$$

Kriteria Pengujian: Jika: $F_{\text {hitung }} \geq F_{\text {tabel }}$ maka $H_{0}$ ditolak. Jika: $F_{\text {hitung }}<F_{\text {tabel }}$ maka $H_{0}$ diterima. $\mathrm{H}_{0}$ diterima berarti varians homogen atau varians antar kelompok tidak ada perbedaan.

Uji t

Analisis data yang digunakan untuk aesain eksperimen ini menggunakan t-test yang berupa independent sample test. Menurut Mulyatiningsih (2014:96) uji independent sample test digunakan untuk menguji dua set data dari kelompok sampel yang berbeda. Uji t ini berfungsi untuk mengetahui kesimpulan penelitian. Hipotesis mana yang diterima diketahui lewat uji $\mathrm{t}$ ini. Dalam uji $\mathrm{t}$ ini, ada ketentuan yang harus dijadikan pedoman.

Ketentuan dalam uji t yaitu jika $t_{\text {hitung }} \leq t_{\text {tabel }}$ maka Ho diterima dan jika $t_{\text {hitung }}>t_{\text {tabel }}$ maka Ho ditolak. Dengan dk = n - 2 dan taraf kesalahan 5\% untuk uji dua pihak. $\mathrm{H}_{0}$ ditolak artinya terdapat pengaruh penerapan metode mind mapping terhadap hasil belajar IPS kelas VIII di SMP N 6 Purwokerto. Hasil belajar IPS lebih tinggi menggunakan metode mind mapping dari pada menggunakan metode ceramah. Menurut Sugiyono (2010:274) rumus uji t adalah sebagai berikut: 
Keterangan :

$$
t=\frac{\bar{X}_{1}-\bar{X}_{2}}{\sqrt{\frac{s_{1}^{2}}{n_{1}}+\frac{s_{2}^{2}}{n_{2}}-2 r\left(\frac{s_{1}}{\sqrt{n_{1}}}\right)\left(\frac{s_{2}}{\sqrt{n_{2}}}\right)}}
$$

$\begin{array}{ll}\bar{X}_{1} & : \text { nilai rata-rata kelompok eksperimen } \\ \bar{X}_{2} & \text { : nilai rata-rata kelompok kontrol } \\ s_{1}^{2} & : \text { varians sampel kelompok eksperimen } \\ s_{2}^{2} & \text { : varians sampel kelompok kontrol } \\ s_{1} & : \text { standar deviasi kelompok eksperimen } \\ s_{2} & : \text { standar deviasi kelompok kontrol } \\ \mathrm{n}_{1} & \text { : jumlah subjek kelompok eksperimen } \\ \mathrm{n}_{2} & \text { : jumlah subjek kelompok kontrol } \\ \mathrm{r} & \text { : koefisien korelasi }\end{array}$

\section{HASIL DAN PEMBAHASAN}

Penelitian ini menggunakan pendekatan eksperimen, sehingga membutuhkan dua kelas untuk dijadikan kelas eksperimen dan kelas kontrol dengan masing-masing kelas diberikan perlakuan yang berbeda tetapi materi pembelajarannya sama yaitu materi pajak dan waktunya juga sama. Perbedaannya terletak pada saat guru menyampaikan materi. Perbedaan cara guru menyampaikan materi bertujuan untuk mengetahui perbedaan hasil belajar IPS pada kelas yang menggunakan metode pembelajaran mind mapping dan kelas yang tidak menggunakan metode mind mapping. Peneliti membandingkan rata-rata nilai IPS kelas setelah siswa diberikan perlakuan untuk melihat ada tidaknya perbedaan. Penelitian dilakukan selama 2 kali pertemuan untuk setiap kelas.

Penelitian dilakukan pada hari Rabu dan Jumat tanggal 7 dan 9 Februari 2018 pukul 12.00-13.20 dan 09.35-10.55. Pada hari Rabu dan Jumat, penelitian ini dilakukan di kelas VIII E sebagai kelas kontrol. Pembelajaran hanya diikuti oleh 34 siswa karena 2 siswa tidak berangkat dan tanpa keterangan. Peneliti yang sekaligus sebagai guru yang mengajar kelas kontrol menjelaskan materi pajak dengan menggunakan metode ceramah dan melakukan pencatatan biasa. Siswa merasa bosan karena siswa lebih banyak berdiam diri untuk mendengarkan cerita guru tanpa berperan secara aktif didalamnya sehingga siswa kurang tertarik untuk belajar. Berdasarkan pembelajaran menggunakan metode ceramah tersebut diperoleh hasil belajar yang dapat dilihat dari tabel 4 dan gambar 1.

Tabel 4 Data hasil post test kelas kontrol tanggal 9 februari 2018

\begin{tabular}{|c|c|c|c|}
\hline No & Kelas Interval & Turus & Frekuensi \\
\hline 1. & $60-70$ & $\mid 111111111111$ & 13 \\
\hline 2. & $71-80$ & |||||||||||||||| $\mid$ & 18 \\
\hline 3. & $81-90$ & 山 & 3 \\
\hline \multicolumn{2}{|c|}{ Jumlah } & 34 & 34 \\
\hline
\end{tabular}

Sumber : Data diolah tahun 2018 


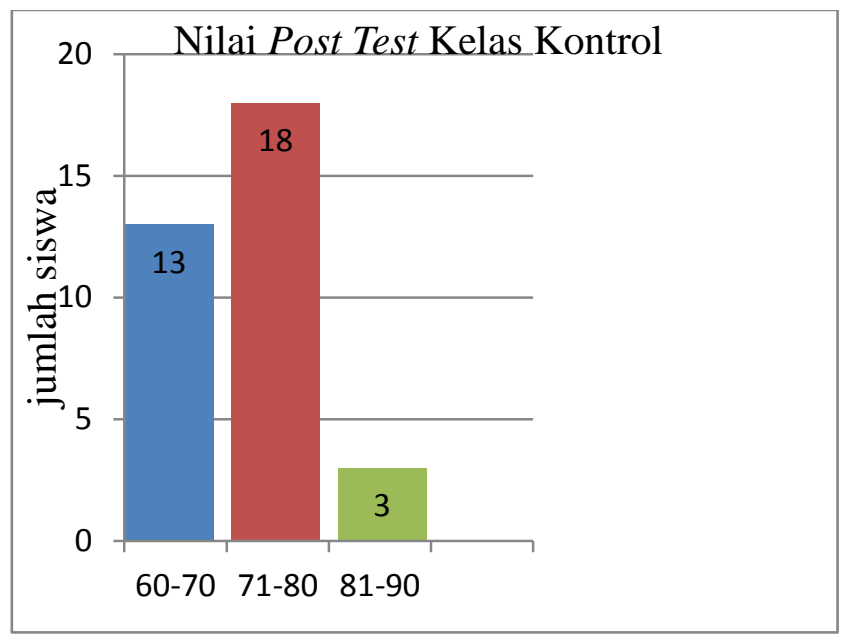

Gambar 1. Diagram hasil belajar IPS kelas kontrol

Berdasarkan tabel 4 dan gambar 1 dapat dilihat sebanyak 13 siswa mendapatkan nilai kisaran 60 sampai 70 . Sebanyak 18 siswa mendapatkan nilai kisaran 71 sampai 80 dan sebanyak 3 siswa mendapatkan nilai kisaran 81 sampai 90. Dalam kelas kontrol tidak ada siswa yang mendapatkan nilai di atas 90. Maksimal nilai yang diperoleh siswa dalam kelas kontrol adalah 86,67 sedangkan nilai minimal yang diperoleh siswa dalam kelas kontrol adalah 60 . Sebanyak 3 siswa yang memperoleh nilai maksimal dan sebanyak 7 siswa yang memperoleh nilai minimal. Kriteria ketuntasan minimal untuk nilai mata pelajaran IPS di SMP N 6 Purwokerto adalah 78 artinya dari tabel 12 dan gambar 4 diatas dapat disimpulkan banyaknya siswa yang mencapai kriteria ketuntasan minimal yang diuji melalui post test sebanyak 12 siswa atau 35,29\% dan 22 siswa atau 64, 71\% belum mencapai kriteria kentuntasan minimal.

Penelitian selanjutnya dilakukan pada hari Senin dan Selasa tanggal 12 dan 13 Februari 2018 pukul 11.15-13.05 dan 09.30-10.50. Pada hari Senin dan Selasa, penelitian ini dilakukan di kelas VIII D sebagai kelas eksperimen. Pembelajaran hanya diikuti oleh 35 siswa karena 2 siswa tidak berangkat dan tanpa keterangan. Peneliti yang sekaligus sebagai guru yang mengajar kelas eksperimen menjelaskan materi pajak dengan menggunakan metode mind mapping. Metode mind mapping adalah cara yang digunakan guru untuk menyampaikan materi menggunakan peta konsep yang bercabang-cabang dan didalamnya terdapat gambar, simbol, angka, dan tulisan yang berwarna untuk memperjelas materi.

Peneliti membuat mind mapping dengan bahan kertas manila yang berwarna putih kemudian menambahkan gambar, kata kunci, angka, dan simbol dengan menggunakan spidol berwarna. Siswa juga berlatih membuat mind map secara sederhana disetiap pertemuan. Siswa membuat mind map menggunakan kertas polio dan spidol berwarna. Siswa tertarik untuk belajar setelah melihat mind map yang berwarna dan bergambar dalam pembelajaran sehingga pembelajaran menjadi kondusif. Setelah pembelajaran siswa diberi post test untuk mengukur hasil belajar IPS menggunakan metode mind mapping. Berdasarkan pembelajaran menggunakan 
metode mind mapping tersebut diperoleh hasil belajar yang dapat dilihat dari tabel 5 dan gambar 2 .

Tabel 5. Data hasil post test kelas eksperimen tanggal 13 februari 2018

\begin{tabular}{|c|c|c|c|}
\hline No & Kelas Interval & Turus & Frekuensi \\
\hline 1. & $60-70$ & IIII & 4 \\
\hline 2. & $71-80$ & 111111111111111111 & 19 \\
\hline 3. & $81-90$ & ||||||| & 8 \\
\hline 4. & 91-100 & 山ل & 4 \\
\hline & Jumlah & 35 & 35 \\
\hline
\end{tabular}

Sumber : Data diolah tahun 2018

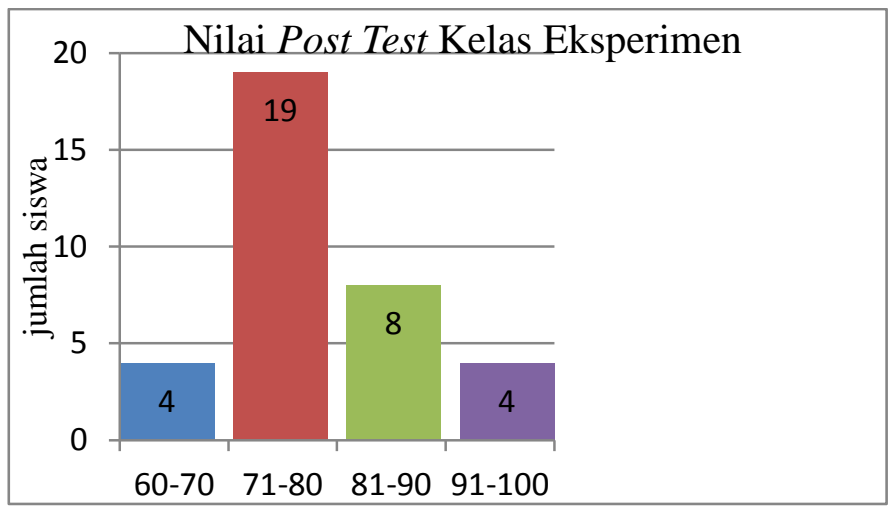

Gambar 2. Diagram hasil belajar kelas eksperimen

Berdasarkan tabel 5 dan gambar 2 diatas dapat dilihat sebanyak 4 siswa mendapatkan nilai kisaran 60 sampai 70. Sebanyak 19 siswa mendapatkan nilai kisaran 71 sampai 80, sebanyak 8 siswa mendapatkan nilai kisaran 81 sampai 90 dan 4 siswa mendapatkan nilai kisaran 91 sampai 100. Dalam kelas eksperimen tidak ada siswa yang mendapatkan nilai 100. Maksimal nilai yang diperoleh siswa dalam kelas eksperimen adalah 93,33 sedangkan nilai minimal yang diperoleh siswa dalam kelas eksperimen adalah 66,67. Empat siswa yang memperoleh nilai maksimal dan sebanyak 4 siswa juga yang memperoleh nilai minimal. Kriteria ketuntasan minimal untuk nilai mata pelajaran IPS di SMP N 6 Purwokerto adalah 78 artinya dari tabel 13 dan gambar 6 dapat disimpulkan banyaknya siswa yang mencapai kriteria ketuntasan minimal yang diuji melalui post test sebanyak 24 siswa atau 68,57\% dan 11 siswa atau $31,43 \%$ belum mencapai kriteria kentuntasan minimal.

Setelah melihat perolehan nilai IPS pada kelas eksperimen dan kelas kontrol maka langkah selanjutnya menghitung rata-rata nilai IPS untuk mengetahui perbedaan atau perbandingan antara kelas eksperimen dan kelas kontrol. Hasil uji rata-rata kelas eksperimen dan kelas kontrol dapat dilihat dari tabel 6. 
Tabel 6. Hasil uji rata-rata kelas eksperimen dan kontrol

\begin{tabular}{lccc}
\hline & Kelas eksperimen & Kelas kontrol \\
\hline $\mathrm{N} \quad$ Valid & 35 & 34 \\
& Missing & 0 & 1 \\
Mean & 80.191 & 72.379 \\
Std. Deviation & .78350 & .85521 \\
Minimum & 66.67 & 60 \\
Maximum & 93.33 & 86.67 \\
\hline
\end{tabular}

Sumber : Data diolah tahun 2018

Berdasarkan hasil penelitian menunjukkan terdapat pengaruh penerapan metode mind mapping terhadap hasil belajar IPS kelas VIII di SMP N 6 Purwokerto. Hasil belajar IPS lebih tinggi menggunakan metode mind mapping dari pada menggunakan metode ceramah. Berdasarkan tabel 14 nilai rata-rata hasil belajar IPS kelas eksperimen lebih tinggi dibandingkan dengan kelas kontrol yaitu 80,2 > 72,4. Hasil post test juga menunjukan siswa yang mencapai kriteria ketuntasan belajar minimal untuk kelas eksperimen lebih tinggi dibandingkan kelas kontrol yaitu $24>12$.

\section{KESIMPULAN}

\section{Kesimpulan}

Hasil penelitian yang telah dilaksanakan di SMP N 6 Purwokerto menunjukkan bahwa terdapat pengaruh penerapan metode mind mapping terhadap hasil belajar IPS kelas VIII di SMP N 6 Purwokerto. Hasil belajar IPS lebih tinggi menggunakan metode mind mapping dari pada menggunakan metode ceramah. Rata-rata nilai kelas eksperimen lebih tinggi dari pada kelas kontrol. Rata rata nilai yang diperoleh kelas eksperimen yaitu 80,2 sementara kelas kontrol sebesar 72,4. Metode pembelajaran mind mapping berpengaruh efektif terhadap hasil belajar siswa. Pengaruh metode pembelajaran mind mapping terhadap hasil belajar ditandai dengan nilai $\mathrm{t}$ hitung $>\mathrm{t}$ tabel yaitu $3,958>1,980$ dan rata-rata nilai kelas eksperimen lebih tinggi dibandingkan dengan kelas kontrol yaitu 80,2 > 72,4.

\section{Implikasi}

Berdasarkan hasil penelitian dan kesimpulan, maka implikasi yang dapat disampaikan peneliti adalah sebagai berikut: (1) Bagi Siswa; Siswa diharapkan dapat mencatat materi dengan menggunakan mind map supaya lebih mudah memahami materi. (2) Bagi Guru; Guru diharapkan mengaplikasikan penggunaan metode mind mapping dalam pembelajaran IPS untuk dapat meningkatkan hasil belajar.(3) Bagi Sekolah; Pihak sekolah diharapkan dapat menambah sarana dan prasarana sekolah, khususnya memberikan fasilitas alat dan bahan dalam membuat mind map, sehingga pembelajaran dengan mind map dapat berjalan dengan baik.(4) Bagi Peneliti Selanjutnya; Peneliti selanjutnya diharapkan dapat menyediakan 
alat dan bahan yang cukup untuk pembuatan mind map dan menambah tatap muka dengan siswa.

\section{DAFTAR PUSTAKA}

Alimuddin, Johar. 2011. Keefektifan Pembelajaran IPS melalui Model Mind Mapping (Peta Pikiran) untuk Mengenal Permasalahan Sosial Di Daerah Setempat Bagi Siswa Kelas IV Sekolah Dasar Negeri 02 Paduraksa. Skripsi. Universitas Negeri Semarang.

Arifah, Isnaini. 2015. Pengaruh Metode Mind Map terhadap Kreativitas dan Prestasi Belajar Kimia Peserta Didik Kelas X Di SMA Negeri 1 Karanganom Klaten Jawa Tengah. Skripsi. Universitas Islam Negeri Sunan Kalijaga. Yogyakarta.

Djamarah. 2002. Psikologi Belajar. Jakarta: Rineka Cipta.

Faridah, Eny, dan Woro Setyarsih. 2014. Pengaruh Penerapan Strategi Peta Pikiran (Mind Mapping) terhadap Hasil Belajar IPA Terpadu Tema Es Lilin Siswa Kelas VIII SMP N 4 Jombang. Jurnal Pendidikan Sains.Vol 02 No 01 Tahun 2014, 130-135. ISSN: 2252-7710.

Handoko, Panji Seno. 2015. Pengaruh Penggunaan Mind Map Terhadap Hasil Belajar IPS Kelas V Semester Genap SD Negeri Margoyasan Yogyakarta Tahun Ajaran 2014/2015 Yogyakarta. Skripsi. Universitas Negeri Yogyakarta.

Kustono. 2016. Pengaruh Minat Belajar Siswa Terhadap Prestasi Belajar dalam Mata Pelajaran IPS Kelas VIII Di SMP Tri Sukses Natar Lampung Selatan. Skripsi. Universitas Lampung.

Mulyatiningsih, Endang. 2014. Metode Penelitian Terapan Bidang Pendidikan. Bandung: Alfabeta. Sudjana, Nana dan Wari Suwariyah. 2010. Model-Model Mengajar CBSA. Bandung: Sinar Baru Algensindo.

Sudjana, Nana. 2014. Penelitian Hasil Proses Belajar Mengajar. Bandung: Remaja Rosdakarya.

Sugiarto, Iwan, 2004. Mengoptimalkan Daya Kerja Otak dengan Berfikir Holistik dan Kreatif, Jakarta: PT Gramedia.

Sugiyono. 2010. Metode Penelitian Kuantitatif Kualitatif \& RND. Bandung: Alfabeta. 2012. Statistika untuk Penelitian. Bandung: Alfabeta.

Suprijono, Agus. 2009. Cooperative Learning Teori dan Aplikasi PAIKEM. Yogyakarta: Pustaka Pelajar.

Sutanto, Ahmad. 2015. Teori Belajar dan Pembelajaran di Sekolah Dasar. Jakarta: Prenada Media Group.

Syah, Muhibbin. 2008. Psikologi Pendidikan dengan Pendekatan Baru. Bandung: PT Remaja Rosdakarya.

Trianto. 2012. Mendesain Model Pembelajaran Inovatif Progresif. Jakarta: Kencana Prenada Media Group. 